\section{B A Institute of \\ YK Business Administration \\ 六下 \\ Karachi \\ Leadership and Ideas for Tomorrow}

Business Review

Volume 11 Issue 1 January-June 2016

$1-1-2016$

\title{
Beta stationarity and estimation period: Evidence from Pakistan's equity market
}

\author{
Sana Tauseef \\ Institute of Business Administration, Karachi, Pakistan
}

Follow this and additional works at: https://ir.iba.edu.pk/businessreview

Part of the Economics Commons

\section{(c) (1)}

This work is licensed under a Creative Commons Attribution 4.0 International License.

\section{Recommended Citation}

Tauseef, S. (2016). Beta stationarity and estimation period: Evidence from Pakistan's equity market. Business Review, 11(1), 1-9. Retrieved from https://doi.org/10.54784/1990-6587.1073

This article is brought to you by iRepository for open access under the Creative Commons Attribution 4.0 License and is available at https://ir.iba.edu.pk/businessreview/vol11/iss1/1. For more information, please contact irepository@iba.edu.pk. 


\title{
ARTICLE
}

\section{Beta Stationarity and Estimation Period: Evidence from Pakistan's Equity Market}

\author{
Sana Tauseef \\ Abstract \\ Institute of Business Administration, Karachi, Pakistan \\ This study examines the stability of individual stock beta coefficients over \\ time and its link with the length of estimation periods. Using data for 325 \\ stocks from Pakistan for the period 1999 to 2012, I show that beta \\ coefficients are not stable on average but become more stable as the \\ estimation period increases. This suggests that longer estimation periods \\ should be used for predicting future beta coefficients.
}

Key Words: Beta, stocks, Karachi Stock Exchange.

JEL Classification: G12, G23.

\section{Introduction}

Risk and return are two most important factors which common stock investors include in their investment analysis. Risk is defined as the uncertainty of the return and is categorized in two components: firm-specific risk and the market risk. When the stocks are combined in a portfolio, the risk caused by the firm-specific factors is diversified. For welldiversified portfolios, the firm-specific risk is completely eliminated and the remaining risk is the market risk only. Thus, the market-related portion of a stock's total risk determines the stock's impact on the risk of the portfolio. Investors demand and receive a higher return from investments which involve higher market risk, implying that the expected returns for equity holders are a positive function of the market risk. The market risk is represented by the beta coefficient in the market model developed by Sharpe (1963). While making the investment decision, an investor assesses the future market risk of an investment based on the historical beta figure. The accurate estimation of beta is, therefore, important for investment decision making.

This paper investigates the stability of individual stock's beta coefficient across time and the impact of the length of estimation interval on the stability of estimated beta coefficients in Pakistan's equity market. Consistent with the findings in existing literature, the beta coefficients for Pakistan's stocks do not show stability across time. Moreover, the beta coefficients estimated using long time intervals exhibit less instability than the beta coefficients estimated using short time intervals.

The paper is organized in the following way: section 2 reviews the relevant literature, sample and methodology are presented in section 3, section 4 presents the findings of the study and section 5 concludes the paper. 


\section{Literature Review}

Stability of beta has been tested empirically in a number of studies. These studies have concluded that the individual security beta is instable and it varies depending on various factors including the estimation period used for beta calculation, time interval between the data points, market conditions, trading volume and liquidity, industry group, size of portfolio examined, extremity of the beta, firm size and differential information.

Many studies have found evidence of beta instability when the estimation period is changed (Levy, 1971; Baesel,1974; Singh, 2008 and Deb \& Mishra, 2011). These studies found evidence of beta instability, particularly over shorter time horizon, at both individual security as well as portfolio levels. This instability is reported to decline as the length of beta estimation period increases.

Beta coefficients are also found to be dependent on the intervals between data points over the estimation period. Singh (2008) reported that the variability of beta is higher with longer interval periods.

Studies relating the stability of beta with the extremity of beta have found the extreme betas (both very low and very high) to be marginally more stable than the intermediate beta values (Baesel, 1974 and Deb \& Mishra, 2011). Stability of beta has also been examined over different market phases. Celik (2013) found evidence of varying beta under different market conditions (bull and bear). However, Levy (1971) reported the stability of beta to be independent of the market direction.

Studies including Levy (1071), Blume (1971) and Alexander and Chervany (1980) concluded that individual security betas are unstable and the time stability of portfolio beta coefficients is directly related to the number of securities in the portfolio. As the number of securities in the portfolio rises, the magnitude of inter-temporal changes in portfolio beta coefficients decreases. Contrary to this, Gregory-Allen, Impson and Karafiath (1994) concluded that portfolio betas are no more stable than individual securities' betas. Singh (2008) concluded that portfolio formation contributes to the beta stationarity only when monthly returns are used.

De Jong and Collins (1985) related the instability of equity beta to the unexpected changes in the risk-free rates and the level of leverage employed by the firm. The firms with relatively higher level of debt were found to exhibit greater beta instability as compared to the firms with relatively lesser debt levels. Moreover, the equity betas were more instable during the periods of relatively large unexpected changes in the risk-free rates.

The issue of beta instability has been explored thoroughly in the developed markets but considerably less evidence is available from developing markets. This paper contributes to the existing literature by presenting the evidence of beta instability from a developing market and it is the first attempt to explore the issue of beta instability in the context of Pakistan's equity market.

\section{Data and Methodology}

The sample of the study consists of the price data on 325 stocks listed on the Karachi Stock Exchange (KSE), for the period of January 1999 to December 2012. The total number of listed companies on KSE in December 2012 was 573. The companies which did not exist throughout the study period and which reported zero returns for a continuous period of 12 months or more are excluded from the sample. KSE-100 index is used as a proxy for the 
market. The adjusted prices for 325 stocks and the KSE-100 indices are extracted from Bloomberg data base.

Using monthly returns, the following basic Market Model is used to calculate the beta values of individual stocks over different time periods:

$$
R_{i, t}=\alpha_{i}+\beta_{i} R_{m, t}+\varepsilon_{i, t}
$$

where,

$$
\begin{gathered}
R_{i, t}=\text { Return on stock } i \text { for month } t \\
R_{m, t}=\text { Return on the market for month } t \\
\alpha \text { and } B=\text { Parameters to be estimated }
\end{gathered}
$$

The beta coefficients are calculated over various estimation periods (one year, two years, three years, etc, up to fourteen years). Table 1 shows the descriptive statistics of these beta coefficients. The mean beta coefficient reduces as the estimation period is increased. This is in contrast to the statistics reported by Deb and Misra (2011) for the Indian equity. The standard deviation of beta coefficients and the range of beta coefficients are smaller for longer estimation periods.

\section{Table 1}

Descriptive Statistics for Beta Values Calculated Using Various Estimation Periods

\begin{tabular}{|c|c|c|c|c|}
\hline Beta Calculated Over: & Mean & Standard Deviation & Minimum & Maximum \\
\hline 1 year & 0.646 & 1.832 & -40.029 & 44.646 \\
\hline 2 years & 0.626 & 1.166 & -27.969 & 15.143 \\
\hline 3 years & 0.603 & 1.018 & -20.148 & 9.167 \\
\hline 4 years & 0.577 & 0.938 & -18.698 & 6.011 \\
\hline 5 years & 0.575 & 0.857 & -17.798 & 4.297 \\
\hline 6 years & 0.572 & 0.803 & -15.800 & 3.955 \\
\hline 7 years & 0.574 & 0.749 & -13.957 & 3.143 \\
\hline 8 years & 0.580 & 0.700 & -12.594 & 2.558 \\
\hline 9 years & 0.589 & 0.631 & -11.394 & 2.456 \\
\hline 10 years & 0.593 & 0.579 & -7.148 & 2.462 \\
\hline 11 years & 0.582 & 0.592 & -6.911 & 2.454 \\
\hline 12 years & 0.572 & 0.618 & -6.578 & 2.172 \\
\hline 13 years & 0.563 & 0.659 & -6.471 & 1.791 \\
\hline 14 years & 0.561 & 0.637 & -6.163 & 1.777 \\
\hline
\end{tabular}

The following approaches are used to measure the stability of beta coefficients across various time periods:

1. A regression model with 13 dummy variables, is used to measure the change in beta coefficients across single calendar year periods, as listed below:

$$
R_{i, t}=\alpha_{i}+\beta_{1} R_{m, t}+\beta_{2} D_{2} R_{m, t}+\ldots \beta_{14} D_{14} R_{m, t}+\varepsilon_{i, t}
$$

where,

$$
\begin{aligned}
& R_{i, t}=\text { Return on stock } i \text { for month } t \\
& D_{2} R_{m, t}=R_{m, t} \text {, if data is for the second year (2000) } \\
& =0 \text {, otherwise } \\
& \text {... }
\end{aligned}
$$




$$
\begin{aligned}
& D_{14} R_{m, t}=R_{m, t} \text {, if data is for the fourteenth year (2012) } \\
& =0 \text {, otherwise } \\
& \alpha \text { and } \beta=\text { Parameters to be estimated }
\end{aligned}
$$

If one or more of the slope coefficients ( $\beta_{I}$ to $\beta_{I 4}$ ) are significant, the hypothesis of beta stability across time will be rejected.

2. Mean difference test is used to test if the mean beta coefficients calculated using different estimation periods (1-year, 2-years till 7-years) are statistically different. If the tstatistics corresponding to the differences of mean beta coefficients are significant, the hypothesis of beta stability will be rejected.

3. Transition matrices are estimated for two sub-periods of 12-months and 84 months with 14 and 2 observations available respectively. For each sub-period, betas are grouped into percentiles (risk classes) on the basis of magnitude, with the first risk class containing $20 \%$ of the stocks with lowest beta values and the fifth risk class containing $20 \%$ of the stocks with highest beta values. The stocks are then cross classified by their risk class in period $t$ and the risk class in period $t+1$ to identify the proportion of stocks switching from one risk class in period $t$ to some other risk class in period $t+1$. For each transition matrix, chisquare statistic is calculated. If the chi-square statistic is significant, the hypothesis that the distribution is a result of pure randomness will be rejected.

4. Product moment correlations and rank order correlations are calculated among the beta coefficients estimated across different time periods and with different estimation intervals. Significance tests of correlation coefficients are used to assess whether the relationships between the beta coefficients are the result of chance. If these correlations are significant, the hypothesis of no relationship between the beta coefficients estimated across different time periods will be rejected.

\section{Empirical Results}

Using the regression model with dummy variables, 248 companies out of 325 companies reported at least one significant slope coefficient. Table 2 presents the total number of companies with positive significant slope coefficients and total number of companies with negative significant slope coefficients. These results show that the beta coefficients are not stable and fluctuate across time.

Table 3 reports the mean differences of the beta coefficients estimated using different estimation periods. Differences of mean beta coefficients are calculated from one year to seven-year estimation period. Most of the mean differences are significant; however, as the estimation period increases the mean differences become less significant suggesting an increase in beta stability for longer estimation periods as compared to shorter estimation periods.

Table $4 \mathrm{~A}$ represents the transition matrix using 14 sequential twelve month subperiods (a total of 4225 observations) and table 4B represents the transition matrix using 2 sequential eighty-four month sub-periods (a total of 325 observations). For each sub-period, betas are grouped into percentiles (risk classes) on the basis of magnitude, with the first risk class containing $20 \%$ of the stocks with lowest beta values and the fifth risk class containing $20 \%$ of the stocks with highest beta values. Each entry in the transition matrix shows the proportion of the stocks falling in risk class $r$ in period $t$ and risk class $r$ in period $t+1$. For example, the first element $(1,1)$ in table $4 \mathrm{~A}$ has a value 0.31 which means $31 \%$ of stocks which were in the lowest risk class in period t. 
Table 2

Results for the Regression Model

\begin{tabular}{|c|c|c|c|}
\hline Coefficient & $\begin{array}{c}\text { Number of Companies } \\
\text { with significant } \\
\text { coefficient }\end{array}$ & $\begin{array}{c}\text { Number of Companies with } \\
\text { positive significant coefficient }\end{array}$ & $\begin{array}{c}\text { Number of Companies with } \\
\text { negative significant coefficient }\end{array}$ \\
\hline $\mathrm{A}$ & 43 & 37 & 6 \\
\hline$\beta_{1}$ & 71 & 65 & 6 \\
\hline$\beta_{2}$ & 44 & 32 & 12 \\
\hline$\beta_{3}$ & 31 & 16 & 15 \\
\hline$\beta_{4}$ & 38 & 23 & 15 \\
\hline$\beta_{5}$ & 51 & 42 & 9 \\
\hline$\beta_{6}$ & 42 & 37 & 5 \\
\hline$\beta_{7}$ & 36 & 20 & 16 \\
\hline$\beta_{8}$ & 23 & 10 & 13 \\
\hline$\beta_{9}$ & 39 & 30 & 9 \\
\hline$\beta_{10}$ & 52 & 32 & 31 \\
\hline$\beta_{11}$ & 65 & 34 & 7 \\
\hline$\beta_{12}$ & 35 & 28 & 8 \\
\hline$\beta_{13}$ & 23 & 15 & 5 \\
\hline$\beta_{14}$ & 61 & 56 & \\
\hline
\end{tabular}

Table 3

Mean Differences of Beta Coefficients Estimated Using Different Estimation Periods

\begin{tabular}{|c|c|c|c|c|c|c|c|c|}
\hline $\begin{array}{c}\text { Estimation } \\
\text { Period }\end{array}$ & 1 year & $1999 \& 2000$ & $2000 \& 2001$ & $2001 \& 2002$ & $2002 \& 2003$ & $2003 \& 2004$ & $2004 \& 2005$ & $2005 \& 2006$ \\
\hline $\begin{array}{c}\text { Mean } \\
\text { Difference }\end{array}$ & & 0.0036 & -0.0581 & -0.0486 & $-0.2861 *$ & $-0.3837 * *$ & $0.6173 * * *$ & $0.1490 * * *$ \\
\hline $\begin{array}{c}\text { Estimation } \\
\text { Period }\end{array}$ & 2 years & $\begin{array}{l}1999-2000 \\
\& 2000-01 \\
\end{array}$ & $\begin{array}{c}2000-01 \& \\
2002-03\end{array}$ & $\begin{array}{c}2001-02 \& \\
2003-04\end{array}$ & $\begin{array}{c}2002-03 \& \\
2004-05 \\
\end{array}$ & $\begin{array}{c}2003-04 \& \\
2005-06 \\
\end{array}$ & $\begin{array}{c}2004-05 \& \\
2006-07\end{array}$ & $\begin{array}{c}2005-06 \& \\
2007-08\end{array}$ \\
\hline $\begin{array}{c}\text { Mean } \\
\text { Difference }\end{array}$ & & -0.0331 & $-0.2051^{*}$ & $-0.4578 * * *$ & -0.0372 & $0.3627 * * *$ & $0.0985 * *$ & $-0.0785^{* *}$ \\
\hline $\begin{array}{c}\text { Estimation } \\
\text { Period }\end{array}$ & 3 years & $\begin{array}{l}1999-2001 \\
\& 2002-04\end{array}$ & $\begin{array}{c}2000-02 \& \\
2003-04\end{array}$ & $\begin{array}{c}2001-03 \& \\
2004-06\end{array}$ & $\begin{array}{c}2002-04 \& \\
2005-07\end{array}$ & $\begin{array}{c}2003-05 \& \\
2006-08\end{array}$ & $\begin{array}{c}2004-06 \& \\
2007-09\end{array}$ & $\begin{array}{c}2005-07 \& \\
2008-10\end{array}$ \\
\hline $\begin{array}{c}\text { Mean } \\
\text { Difference }\end{array}$ & & $-0.2921 * * *$ & $-0.3330 * * *$ & -0.0985 & $0.1237 * *$ & 0.1910 & $0.0749 *$ & -0.0094 \\
\hline $\begin{array}{c}\text { Estimation } \\
\text { Period }\end{array}$ & 4 years & $\begin{array}{l}1999-2002 \\
\& 2003-06 \\
\end{array}$ & $\begin{array}{c}2000-03 \& \\
2004-07\end{array}$ & $\begin{array}{c}2001-04 \& \\
2005-08\end{array}$ & $\begin{array}{c}2002-05 \& \\
2006-09 \\
\end{array}$ & $\begin{array}{c}2003-06 \& \text { } \\
2007-10\end{array}$ & $\begin{array}{c}2004-07 \& \\
2008-11\end{array}$ & $\begin{array}{c}2005-08 \& \\
2009-12 \\
\end{array}$ \\
\hline $\begin{array}{c}\text { Mean } \\
\text { Difference }\end{array}$ & & $-0.3029 * * *$ & $-0.1583^{*}$ & 0.0184 & $0.1395 * * *$ & $0.1135 * *$ & 0.0561 & $-0.1786 * * *$ \\
\hline $\begin{array}{c}\text { Estimation } \\
\text { Period }\end{array}$ & 5 years & $\begin{array}{l}1999-2003 \\
\& 2004-08 \\
\end{array}$ & $\begin{array}{c}2000-04 \& \\
2005-09\end{array}$ & $\begin{array}{c}2001-05 \& \\
2006-10\end{array}$ & $\begin{array}{c}2002-06 \& \\
2007-11 \\
\end{array}$ & $\begin{array}{c}2003-07 \& \\
2008-12 \\
\end{array}$ & & \\
\hline $\begin{array}{c}\text { Mean } \\
\text { Difference }\end{array}$ & & $-0.1373^{*}$ & -0.0206 & -0.0140 & $0.0851 * *$ & 0.0526 & & \\
\hline $\begin{array}{c}\text { Estimation } \\
\text { Period }\end{array}$ & 6 years & $\begin{array}{l}1999-2004 \\
\& 2005-10 \\
\end{array}$ & $\begin{array}{c}2000-05 \& \\
2006-11\end{array}$ & $\begin{array}{c}2001-06 \& \\
2007-12 \\
\end{array}$ & & & & \\
\hline $\begin{array}{c}\text { Mean } \\
\text { Difference }\end{array}$ & & -0.0396 & -0.0736 & -0.0795 & & & & \\
\hline $\begin{array}{c}\text { Estimation } \\
\text { Period }\end{array}$ & 7 years & $\begin{array}{l}1999-2005 \\
\& 2006-12 \\
\end{array}$ & & & & & & \\
\hline $\begin{array}{c}\text { Mean } \\
\text { Difference }\end{array}$ & & $-0.1345^{*}$ & & & & & & \\
\hline
\end{tabular}


Business Review - Volume 11 Number 1

January - June 2016

Table 3 (continued...)

\begin{tabular}{|c|c|c|c|c|c|c|}
\hline $\begin{array}{c}\text { Estimation } \\
\text { Period }\end{array}$ & $2006 \& 2007$ & $2007 \& 2008$ & $2008 \& 2009$ & $2009 \& 2010$ & $2010 \& 2011$ & 2011 \& 2012 \\
\hline $\begin{array}{c}\text { Mean } \\
\text { Difference }\end{array}$ & $-0.2503 * * *$ & $0.1435 * * *$ & $0.1487 *$ & $-0.7159 * * *$ & $0.4618 * * *$ & $-0.4120 *$ \\
\hline $\begin{array}{c}\text { Estimation } \\
\text { Period }\end{array}$ & $\begin{array}{c}2006-07 \& \\
2008-09\end{array}$ & $\begin{array}{c}2007-08 \& \\
2009-10\end{array}$ & $\begin{array}{c}2008-09 \& \\
2010-11\end{array}$ & $\begin{array}{c}2009-10 \& \\
2011-12\end{array}$ & & \\
\hline $\begin{array}{c}\text { Mean } \\
\text { Difference }\end{array}$ & 0.0694 & -0.0370 & $-0.3965 * * *$ & $-0.4403 * * *$ & & \\
\hline $\begin{array}{c}\text { Estimation } \\
\text { Period }\end{array}$ & $\begin{array}{c}2006-08 \& \\
2009-11\end{array}$ & $\begin{array}{c}2007-09 \& \\
2010-12\end{array}$ & & & & \\
\hline $\begin{array}{c}\text { Mean } \\
\text { Difference }\end{array}$ & $-0.0899 *$ & $-0.5170 * * *$ & & & \\
\hline
\end{tabular}

$* * *, * *$ and $*$ indicate that the difference is positive and significant at $1 \%, 5 \%$ and $10 \%$ level of significance.

Table 4A

Transition Matrix Using 12-month Estimation Interval

\begin{tabular}{|c|c|c|c|c|c|c|}
\hline \multicolumn{7}{|c|}{ Risk Class in Period t+1 } \\
\hline \multirow{4}{*}{$\begin{array}{c}\text { Risk Class in } \\
\text { Period t }\end{array}$} & 1 & 1 & 2 & 3 & 4 & 5 \\
\cline { 2 - 7 } & 2 & 0.31 & 0.23 & 0.17 & 0.13 & 0.16 \\
\cline { 2 - 7 } & 3 & 0.19 & 0.22 & 0.21 & 0.20 & 0.18 \\
\cline { 2 - 7 } & 4 & 0.13 & 0.18 & 0.22 & 0.27 & 0.20 \\
\cline { 2 - 7 } & 5 & 0.15 & 0.13 & 0.17 & 0.20 & 0.34 \\
\hline
\end{tabular}

Chi-square statistic is 299.7 which is significant at $1 \%$ level.

Table 4B

Transition Matrix Using 84-month Estimation Interval

\begin{tabular}{|c|c|c|c|c|c|c|}
\hline \multicolumn{7}{|c|}{ Risk Class in Period t+1 } \\
\hline \multirow{3}{*}{$\begin{array}{c}\text { Risk Class in } \\
\text { Period t }\end{array}$} & 1 & 1 & 2 & 3 & 4 & 5 \\
\cline { 2 - 7 } & 2 & 0.20 & 0.38 & 0.25 & 0.11 & 0.06 \\
\cline { 2 - 7 } & 3 & 0.25 & 0.12 & 0.22 & 0.30 & 0.11 \\
\cline { 2 - 7 } & 4 & 0.06 & 0.11 & 0.08 & 0.29 & 0.47 \\
\cline { 2 - 7 } & 5 & 0.09 & 0.12 & 0.35 & 0.17 & 0.27 \\
\hline
\end{tabular}

Chi-square statistic is 105 which is significant at $1 \%$ level remained in the lowest risk class in period $t+1$.From table $4 \mathrm{~A}$, we find that using the one-year estimation period $27 \%$ of the stocks on average remain in the same risk class; Whereas, $73 \%$ of the stocks moved from one risk class to the other exhibiting signs of beta instability. The percentage of stocks remaining in the same risk class is marginally higher for the highest beta values (34\%) and lowest beta values $(31 \%)$. As the estimation period is increased, the percentage of stocks sticking to the same risk class increases (31\% on average for seven-year estimation period in table 4B). However, for a longer estimation period only the lowest beta values show more stability. The chi-square statistic is used to test the hypothesis that the proportions of securities moving from one risk class to the other over the sub-periods used are same. In both 
tables, the chi-square statistic is significant showing that the observed results do not occur by chance.

Table 5 shows the mean product moment correlation coefficients and rank order correlation coefficients among the beta coefficients for different estimation intervals. Tables $6 \mathrm{~A}$ and $6 \mathrm{~B}$ show the product moment correlation coefficients and rank order correlation coefficients, respectively; Among them the beta coefficients are estimated across different time periods and with different estimation intervals. Most of the correlation coefficients are positive and significant which shows that the relationships between the beta coefficients across time are not the result of chance. Moreover, the mean correlation increases as the estimation period increases which shows that the historical beta coefficients calculated using longer estimation period are better in predicting the future beta coefficients.

Table 5

Product Moment Correlation Coefficients and Rank Order Correlation Coefficients

\begin{tabular}{|c|c|c|}
\hline Estimation Period Length & $\begin{array}{c}\text { Mean Product Moment } \\
\text { Correlation Coefficient }\end{array}$ & $\begin{array}{c}\text { Mean Rank Order Correlation } \\
\text { Coefficient }\end{array}$ \\
\hline 1 & -0.007 & 0.220 \\
\hline 2 & 0.196 & 0.317 \\
\hline 3 & 0.190 & 0.351 \\
\hline 4 & 0.200 & 0.383 \\
\hline 5 & 0.206 & 0.422 \\
\hline 6 & 0.149 & 0.404 \\
\hline 7 & 0.173 & 0.414 \\
\hline
\end{tabular}

Table 6A

Product Moment Correlation Coefficients Among Beta Coefficients Estimated Across Different Time Periods and with Different Estimation Intervals

\begin{tabular}{|c|c|c|c|c|c|c|c|c|}
\hline $\begin{array}{c}\text { Estimation } \\
\text { Period }\end{array}$ & 1 year & $1999 \& 2000$ & $2000 \& 2001$ & $2001 \& 2002$ & $2002 \& 2003$ & $2003 \& 2004$ & $2004 \& 2005$ & $2005 \& 2006$ \\
\hline MD & & -0.375 & -0.353 & $0.135 * * *$ & -0.094 & -0.072 & $0.131 * * *$ & 0.028 \\
\hline $\begin{array}{c}\text { Estimation } \\
\text { Period }\end{array}$ & 2 years & $\begin{array}{l}1999-2000 \\
\& 2000-01\end{array}$ & $\begin{array}{c}2000-01 \& \\
2002-03\end{array}$ & $\begin{array}{c}2001-02 \& \\
2003-04\end{array}$ & $\begin{array}{c}2002-03 \& \\
2004-05\end{array}$ & $\begin{array}{c}2003-04 \& \\
2005-06\end{array}$ & $\begin{array}{c}2004-05 \& \\
2006-07\end{array}$ & $\begin{array}{c}2005-06 \& \\
2007-08\end{array}$ \\
\hline MD & & $0.715 * * *$ & $0.213 * * *$ & -0.065 & $0.077 *$ & $0.150 * * *$ & 0.0378 & $0.216^{* * * *}$ \\
\hline $\begin{array}{c}\text { Estimation } \\
\text { Period }\end{array}$ & 3 years & $\begin{array}{l}1999-2001 \\
\& 2002-04\end{array}$ & $\begin{array}{c}2000-02 \& \\
2003-04\end{array}$ & $\begin{array}{c}2001-03 \& \\
2004-06\end{array}$ & $\begin{array}{c}2002-04 \& \\
2005-07\end{array}$ & $\begin{array}{c}2003-05 \& \\
2006-08\end{array}$ & $\begin{array}{c}2004-06 \& \& \\
2007-09 \\
\end{array}$ & $\begin{array}{c}2005-07 \& \\
2008-10\end{array}$ \\
\hline MD & & $0.214 * * *$ & 0.028 & $0.126^{* * *}$ & $0.209 * * *$ & $0.182 * * *$ & $0.190 * * *$ & $0.248 * * *$ \\
\hline $\begin{array}{l}\text { Estimation } \\
\text { Period }\end{array}$ & 4 years & $\begin{array}{l}1999-2002 \\
\& 2003-06\end{array}$ & $\begin{array}{c}2000-03 \& \\
2004-07\end{array}$ & $\begin{array}{c}2001-04 \& \\
2005-08\end{array}$ & $\begin{array}{c}2002-05 \& \\
2006-09\end{array}$ & $\begin{array}{c}2003-06 \& \\
2007-10\end{array}$ & $\begin{array}{c}2004-07 \& \\
2008-11\end{array}$ & $\begin{array}{c}2005-08 \& \& \\
2009-12\end{array}$ \\
\hline MD & & $0.083 *$ & $0.153 * * *$ & $0.208 * * *$ & $0.231 * * *$ & $0.178 * * *$ & $0.236 * * *$ & $0.313 * * *$ \\
\hline $\begin{array}{c}\text { Estimation } \\
\text { Period }\end{array}$ & 5 years & $\begin{array}{l}1999-2003 \\
\& 2004-08\end{array}$ & $\begin{array}{c}2000-04 \& \\
2005-09\end{array}$ & $\begin{array}{c}2001-05 \& \\
2006-10\end{array}$ & $\begin{array}{c}2002-06 \& \\
2007-11\end{array}$ & $\begin{array}{c}2003-07 \& \\
2008-12\end{array}$ & & \\
\hline MD & & $0.218 * * *$ & $0.150 * * *$ & $0.147 * * *$ & $0.279 * * *$ & $0.239 * * *$ & & \\
\hline $\begin{array}{c}\text { Estimation } \\
\text { Period }\end{array}$ & 6 years & $\begin{array}{l}1999-2004 \\
\& 2005-10\end{array}$ & $\begin{array}{c}2000-05 \& \\
2006-11\end{array}$ & $\begin{array}{c}2001-06 \& \\
2007-12 \\
\end{array}$ & & & & \\
\hline $\mathrm{MD}$ & & $0.184 * * *$ & $0.114 * *$ & $0.149 * * *$ & & & & \\
\hline $\begin{array}{c}\text { Estimation } \\
\text { Period }\end{array}$ & 7 years & $\begin{array}{l}1999-2005 \\
\& 2006-12\end{array}$ & & & & & & \\
\hline MD & & $0.173 * * *$ & & & & & & \\
\hline
\end{tabular}


Business Review - Volume 11 Number 1

January - June 2016

Table 6A (Continued...)

\begin{tabular}{|c|c|c|c|c|c|c|c|}
\hline $\begin{array}{c}\text { Estimation } \\
\text { Period }\end{array}$ & 1 year & $2006 \& 2007$ & $2007 \& 2008$ & $2008 \& 2009$ & $2009 \& 2010$ & $2010 \& 2011$ & $2011 \& 2012$ \\
\hline MD & & 0.031 & $0.190^{* * *}$ & $0.203^{* * *}$ & $0.115^{* *}$ & -0.055 & 0.019 \\
\hline $\begin{array}{c}\text { Estimation } \\
\text { Period }\end{array}$ & 2 years & $\begin{array}{c}2006-07 \& \\
2008-09\end{array}$ & $\begin{array}{c}2007-08 \& \\
2009-10\end{array}$ & $\begin{array}{c}2008-09 \& \\
2010-11\end{array}$ & $\begin{array}{c}2009-10 \& \\
2011-12\end{array}$ & & \\
\hline MD & & $0.187^{* * *}$ & $0.243^{* * *}$ & $0.166^{* * *}$ & $0.220^{* * *}$ & & \\
\hline $\begin{array}{c}\text { Estimation } \\
\text { Period }\end{array}$ & 3 years & $\begin{array}{c}2006-08 \& \\
2009-11\end{array}$ & $\begin{array}{c}2007-09 \& \\
2010-12\end{array}$ & & & & \\
\hline MD & & $0.254^{* * *}$ & $0.256^{* * *}$ & & & & \\
\hline
\end{tabular}

$* * *, * *$ and $*$ indicate that the difference is positive and significant at $1 \%, 5 \%$ and $10 \%$ level of significance. MD is the mean difference.

Table 6B

Rank Order Correlation Coefficients Among Beta Coefficients Estimated Across Different Time Periods and with Different Estimation Intervals

\begin{tabular}{|c|c|c|c|c|c|c|c|c|}
\hline $\begin{array}{c}\text { Estimation } \\
\text { Period }\end{array}$ & 1 year & $1999 \& 2000$ & $2000 \& 2001$ & $2001 \& 2002$ & $2002 \& 2003$ & $2003 \& 2004$ & $2004 \& 2005$ & $2005 \& 2006$ \\
\hline MD & & $0.320 * * *$ & $0.369 * * *$ & $0.382 * * *$ & $0.306 * * *$ & $0.175 * * *$ & $0.107 * *$ & $0.158 * * *$ \\
\hline $\begin{array}{c}\text { Estimation } \\
\text { Period }\end{array}$ & 2 years & $\begin{array}{l}1999-2000 \\
\& 2000-01\end{array}$ & $\begin{array}{c}2000-01 \& \\
2002-03\end{array}$ & $\begin{array}{c}2001-02 \& \\
2003-04\end{array}$ & $\begin{array}{c}2002-03 \& \\
2004-05\end{array}$ & $\begin{array}{c}2003-04 \& \\
2005-06\end{array}$ & \begin{tabular}{|c|}
$2004-05 \&$ \\
$2006-07$
\end{tabular} & $\begin{array}{c}2005-06 \& \\
2007-08\end{array}$ \\
\hline MD & & $0.391 * * *$ & $0.483 * * *$ & $0.338 * * *$ & $0.281 * * *$ & $0.268 * * *$ & $0.198 * * *$ & $0.294 * * *$ \\
\hline $\begin{array}{c}\text { Estimation } \\
\text { Period }\end{array}$ & 3 years & $\begin{array}{l}1999-2001 \\
\& 2002-04\end{array}$ & $\begin{array}{c}2000-02 \& \\
2003-04\end{array}$ & $\begin{array}{c}2001-03 \& \\
2004-06\end{array}$ & $\begin{array}{c}2002-04 \& \\
2005-07\end{array}$ & $\begin{array}{c}2003-05 \& \\
2006-08\end{array}$ & $\begin{array}{c}2004-06 \& \& \\
2007-09\end{array}$ & $\begin{array}{c}2005-07 \& \\
2008-10\end{array}$ \\
\hline MD & & $0.459 * * *$ & $0.438 * * *$ & $0.321 * * *$ & $0.329 * * *$ & $0.362 * * *$ & $0.258 * * *$ & $0.337 * * *$ \\
\hline $\begin{array}{c}\text { Estimation } \\
\text { Period }\end{array}$ & 4 years & $\begin{array}{l}1999-2002 \\
\& 2003-06\end{array}$ & $\begin{array}{c}2000-03 \& \\
2004-07\end{array}$ & $\begin{array}{c}2001-04 \& \\
2005-08\end{array}$ & $\begin{array}{c}2002-05 \& \\
2006-09\end{array}$ & $\begin{array}{c}2003-06 \& \text { \& } \\
2007-10\end{array}$ & \begin{tabular}{|c|}
$2004-07 \&$ \\
$2008-11$
\end{tabular} & $\begin{array}{c}2005-08 \& \\
2009-12\end{array}$ \\
\hline MD & & $0.401 * * *$ & $0.408 * * *$ & $0.402 * * *$ & $0.364 * * *$ & $0.344 * * *$ & $0.346^{* * *}$ & $0.418 * * *$ \\
\hline $\begin{array}{c}\text { Estimation } \\
\text { Period }\end{array}$ & 5 years & $\begin{array}{l}1999-2003 \\
\& 2004-08\end{array}$ & $\begin{array}{c}2000-04 \& \\
2005-09\end{array}$ & $\begin{array}{c}2001-05 \& \\
2006-10\end{array}$ & $\begin{array}{c}2002-06 \& \text { \& } \\
2007-11\end{array}$ & $\begin{array}{c}2003-07 \& \\
2008-12\end{array}$ & & \\
\hline MD & & $0.461 * * *$ & $0.437 * * *$ & $0.370 * * *$ & $0.391 * * *$ & $0.452 * * *$ & & \\
\hline $\begin{array}{c}\text { Estimation } \\
\text { Period }\end{array}$ & 6 years & $\begin{array}{l}1999-2004 \\
\& 2005-10\end{array}$ & $\begin{array}{c}2000-05 \& \\
2006-11\end{array}$ & $\begin{array}{c}2001-06 \& \& \\
2007-12\end{array}$ & & & & \\
\hline MD & & $0.411 * * *$ & $0.421 * * *$ & 0.381 *** & & & & \\
\hline $\begin{array}{c}\text { Estimation } \\
\text { Period }\end{array}$ & 7 years & $\begin{array}{l}1999-2005 \\
\& 2006-12\end{array}$ & & & & & & \\
\hline MD & & 0.4143 & & & & & & \\
\hline
\end{tabular}

Table 6B (Continued...)

\begin{tabular}{|l|l|l|l|l|l|l|l|}
\hline $\begin{array}{l}\text { Estimation } \\
\text { Period }\end{array}$ & 1 year & $\begin{array}{l}2006 \& \\
2007\end{array}$ & $\begin{array}{l}2007 \& \\
2008\end{array}$ & $\begin{array}{l}2008 \& \\
2009\end{array}$ & $\begin{array}{l}2009 \& \\
2010\end{array}$ & $\begin{array}{l}2010 \& \\
2011\end{array}$ & $\begin{array}{l}2011 \& \\
2012\end{array}$ \\
\hline MD & & $0.147 * * *$ & $0.266^{* * *}$ & $0.324 * * *$ & $0.111 * * *$ & $0.096 * *$ & $0.093 * *$ \\
\hline Estimation & 2 & $\begin{array}{l}2006-07 \& \\
\text { Period }\end{array}$ & $\begin{array}{l}2007-08 \& \text { \& } \\
2009-10\end{array}$ & $\begin{array}{l}2008-09 \& \\
2010-11\end{array}$ & $\begin{array}{l}2009-10 \& \text { \& } \\
2011-12\end{array}$ & & \\
\hline MD & & $0.275 * * *$ & $0.375^{* * *}$ & $0.188^{* * *}$ & $0.393 * * *$ & & \\
\hline Estimation & 3 & $2006-08 \&$ & $2007-09 \&$ & & & & \\
Period & years & $2009-11$ & $2010-12$ & & & & \\
\hline MD & & $0.359 * * *$ & $0.298^{*} * *$ & & & & \\
\hline
\end{tabular}

$* * *, * *$ and $*$ indicate that the difference is positive and significant at $1 \%, 5 \%$ and $10 \%$ level of significance. MD is the mean difference.

\section{Conclusion}

This paper examines the stability of individual stock's beta coefficient across time and the impact of the length of estimation interval on the stability of estimated beta 
coefficients using the price data of 325 stocks listed on the Karachi Stock Exchange (KSE), for the period from January 1999 to December 2012. Empirical results show that the beta coefficients are not stable and they fluctuate across time. Moreover, the beta instability decreases as the estimation period increases suggesting that the historical beta coefficients calculated using longer estimation period are better in predicting the future beta coefficients.

This study uses the monthly returns for estimation of beta coefficients of individual stocks. The issue of beta stability can be explored using daily or weekly returns. Further, research can also be done to investigate the stability of beta coefficients for portfolios.

\section{References}

Alexander, G.J. and Chervany, N.L. (1980). On the Estimation and Stability of Beta. Journal of Financial and Quantitative Analysis, 15(1), 123-137.

Baesel, J.B. (1974). On the Assessment of Risk: Some Further Considerations. The Journal of Finance, 29(5), 1491-1494.

Bildersee, J.S. and Roberts, G.S. (1981). Beta Instability when Interest Rates Levels Change. Journal of Financial and Quantitative Analysis, 16(3), 375-380.

Blume, M.E. (1971). On the Assessment of Risk. The Journal of Finance, 26(1), 1-10.

Blume, M. E. (1975). Betas and Their Regression Tendencies. The Journal of Finance, 30(3), 785-795.

Celik, S. (2013). Testing the Stability of Beta: A Sectoral Analysis in Turkish Stock Market. Journal of Economics and Behavioral Studies, 5(1), 18-23.

Deb, S.G. and Mishra, M. (2011). Are Equity Betas Stable? Evidence from Indian Equity Market. The IUP Journal of Applied Finance, 17(4), 5-25.

DeJong, D.V. and Collins, D.W. (1985) Explanations for the Instability of Equity Beta: RiskFree Rate Changes and Leverage Effects. Journal of Financial and Quantitative Analysis, 20(1), 73-94.

Gregory-Allen, R, Impson, C.M. and Karafiath, I. (1994). An Empirical Investigation of Beta Stability: Portfolios Vs. Individual Securities. Journal of Business Finance and Accounting, 21(6), 909-916.

Levy, R.A. (1971). On the Short-Term Stationarity of Beta Coefficients. Financial Analyst Journal,27(6), 55-62.

Mayers, S. L. (1973). The Stationarity Problem in the Use of the Market Model of Security Price Behavior. The Accounting Review,48(2), 318-322.

Ray, K.K. (2010). Stability of Beta over Market Phases: An Empirical Study on Indian Stock Market. International Research Journal of Finance and Economics. 50, 174-189.

Sharpe, W.F. (1963). A Simplified Model for Portfolio Analysis. Management Science, 9(2), 277-293.

Sharp, W.F. and Cooper, G.M. (1972). Risk-Return Classes of New York Stock Exchange Common stocks. Financial Analyst Journal,28(2), 46-54.

Singh, R. (2008). Beta Estimation in the Indian Stock Market: Stability, Stationarity and Computational Considerations. Decisions, 35(2), 63-85.

Theobald, M. (1980). An Analysis of the Market Model and Beta Factors Using U.K. Equity Share Data. Journal of Business Finance and Accounting, 7(1), 49-64. 